\title{
PENERAPAN PRINSIP AKUNTABILITAS DAN TRANSPARANSI PADA PENGELOLAAN BMT DI KOTA SURAKARTA (Studi pada BMT Al-Madinah)
}

\author{
Usnan \\ uus.azzaleamu@gmail.com \\ Fakultas Ekonomi dan Bisnis IAIN Surakarta
}

ABSTRACT

\begin{abstract}
This research was conducted with the aim to find out how the application of the principles of accountability and transparency in the management of the Baitul Maal wat Tamwil (BMT) in Surakarta City with a study at KSUS BMT Al-Madinah Surakarta, which was conducted in 2018. This research is qualitative research, where data obtained through interview techniques and documentation then analyzed descriptively.

The results showed that BMT Al-Madinah Surakarta had applied the principle of accountability consisting of; (1) legal accountability through compliance with the fulfillment of institutional legal aspects and fulfillment of DPS requirements and the implementation of the role of DPS at BMT Al-Madinah, (2) process accountability with the existing jobdescription and reward and punishment for all employees and the implementation of the system information in implementing financial / accounting functions; (3) program accountability through the implementation of programs that are always strived to achieve targets and involve the role of BMT members in determining program plans and targets to be achieved. While the principle of transparency is applied by BMT Al-Medina through the mechanism of RAT and the delivery of various information related to financial information, management and activities carried out through mobile media (whatsapp).
\end{abstract}

Keywords: Accountability, Transparency.

\section{PENDAHULUAN}

BMT mempunyai peran penting dalam perekonomian nasional, yang diantaranya dapat dilihat dari tujuan hadirnya BMT yaitu dalam rangka meningkatkan kualitas usaha ekonomi para anggota menuju kesejahteraan (Sudarsono, 2007; 10). Adapun peran nyata dari eksistensi BMT bagi perekonomian nasional tersebut dapat dilihat dari peningkatan jumlah BMT tahun dari tahun ke tahun, yang hingga tahun 2016 lalu saja, jumlah BMT diperkirakan telah mencapai sekitar 6000 unit. Ditengah pertumbuhan dan perkembangan tersebut, BMT sebagai

lembaga jasa keuangan yang berada dibawah naungan kementerian koperasi, BMT masih menghadapi beberapa ancaman yang dapat menurunkan kepercayaan masyarakat terhadap eksistensi dan perkembangannya, yaitu dengan masih adanya kasus beberapa BMT, diantaranya yaitu pada tahun 2015 di Malang, berkaitan dengan kasus yang terjadi di BMT PSU (www2.jawapos.com, diakses pada 20 Juli 2017) . Berikutnya pada tahun 2017 juga, kasus likuiditas yang terjadi pada BMT di Wonogiri, yang disebabkan BMT mengalami kerugian hingga 
mencapai 16 miliar rupiah (kebumenekspres.com, diakses pada 20 Juli 2017).

Selain kedua kasus tersebut, BMT juga secara implementatif masih mengalami beberapa kekurangan dari aspek penerapan akuntabilitas, misalnya permasalahan yang terkait dengan akuntabilitas dari dimensi proses (pencatatan dan pelaporan keuangan). Hal tersebut didasarkan pada beberapa temuan hasil penelitian diantaranya yaitu penelitian yang dilakukan Darius Leno (2013) tentang Implementasi SAK 101 di Koperasi Simpan Pinjam Syariah Rasau, bahwa Laporan Keuangan di BMT Muhamadiyah Rasau belum sesuai dengan PSAK 101. Juga penelitian yang dilakukan oleh Yenni Aprilia tentang Analisis Penerapan Akuntansi pada Koperasi BMT Islamic Centre di Siak Sri Indrapura, menemukan hasil pula bahwa Koperasi BMT Islamic Centre belum menerapkan Standar Akuntansi Syariah (PSAK 59).

Berangkat dari beberapa kasus tersebut, pengelolaan BMT sebagai sebagai sebuah lembaga keuangan yang berbadan hukum koperasi, aspek transparansi dan akuntabilitas menjadi syarat mutlak bagi keberlangsungan dan perkembangannya. Koperasi tidak akan bangkrut ketika pengurus mengelolanya dengan baik, transparan dan akuntabel (yskk.org). Selain itu, kaitannya pula dengan substansi dari akuntabilitas BMT, Pujiyono (2013) menyatakan bahwa diantara strategi yang harus dimiliki oleh BMT untuk meningkatkan perannya dalam memberdayakan sektor mikro adalah dengan meningkatkan aspek legalitas menuju koperasi modern, konsisten dengan aspek-aspek syariah, dan manajemen yang handal dan profesional.

Beberapa deskripsi diatas mendorong peneliti untuk menggali secara lebih mendalam tentang bagaimana prinisip-prinsip akuntabilitas dan transparansi dilaksanakan oleh BMT yang berada di kota Surakarta. Pemilihan objek penelitian kota surakarta adalah karena surakarta merupakan salah satu daerah di Jawa Tengah, yang mana jawa tengah merupakan daerah dengan urutan ketiga dalam perkembangan jumlah BMT secara nasional, selain itu, pemilihan BMT di Wilayah Kota Surakarta dilatarbelakangi pula oleh hasil pengamatan sementara peneliti berkaitan dengan publikasi melalui media internet (website) yang belum dimiliki oleh BMT di Wilayah Kota Surakarta, padahal saat ini, website sebuah lembaga merupakan sarana untuk mengukur akuntabilitas dan transparansi. Disamping itu, beberapa BMT diSurakarta juga sudah cukup lama berdiri, bahkan ada yang asetnya sudah cukup besar, sehingga menurut peneliti, sangat perlu untuk terus dilakukan evaluasi terhadap penerapan akuntabilitas dan transparansi pengelolaannya, selain itu, salah satu BMT di Surakarta juga memiliki bentuk badan hukum yang berbeda dengan BMT yang lain, yaitu Koperasi Serba Usaha Syariah (KSUS), yaitu BMT AlMadinah Surakarta.

Berangkat dari latar belakang dan alasan pemilihan objek penelitian yang telah dipaparkan diatas maka judul penelitian ini adalah "Penerapan Prinsip Akuntabilitas dan Transparansi pada Pengelolaan BMT di Kota Surakarta dengan Studi pada KSUS BMT Al-Madinah Surakarta”.

\section{KERANGKA TEORITIS}

Akuntabilitas dan transparansi

Akuntabilitas adalah kewajiban seseorang atau unit organisasi untuk mempertanggungjawabkan pengelolaan dan pengendalian sumberdaya dan pelaksanaan kebijakan yang 
dipercayakan kepadanya dalam rangka pencapaian tujuan yang telah ditetapkan (Rakhmat, 2009). Akuntabilitas juga didefinisikan sebagai suatu perwujudan kewajiban untuk mempertanggungjawabkan keberhasilan atau kegagalan dalam pencapaian misi organisasi dan tujuan yang telah ditetapkakan, melalui media pertanggungjawaban yang dilaksanakan secara periodik (Sedarmayanti,2003). Sedangkan dalam LAN (2015) akuntabilitas didefinisikan sebagai kewajiban setiap individu, kelompok atau institusi untuk memenuhi tanggung jawabyang menjadi amanahnya. Wasistiono

mendeskripsikan lima perspektif akuntabilitas, yaitu: (a) Akuntabilitas administratif/organisasi, yaitu pertanggungjawaban antara pejabat yang berwenang dengan unit bawahanya dalam hubungan hierarki yang jelas, (b) Akuntabilitas legal yang ukurannya berupa peraturan perundangundangan yang berlaku, (c) Akuntabilitas politik, berhubungan dengan adanya kewenangan pemegang kekuasaan politik untuk mengatur, menetapkan prioritas dan pendistribusian sumber-sumber yang menjamin adanya kepatuhan melaksanakan tanggungjawab administrasi dan legal, memusatkan pada tekanan demokratik yang dinyatakan oleh administrasi publik, (d) Akuntabilitas professional berkaitan dengan pelaksnaan kinerja dan tindakan berdasarkan tolak ukur yang ditetapkan oleh organisasi profesi yang sejenis. Akuntabilitas ini lebih menekankan pada aspek kualitas kinerja dan tindakan, dan (e) Akuntabilitas moral, yaitu akuntabilitas yang berkaitan dengan tata nilai yang berlaku di kalangan masyarakat.

Untuk merealisasikan lembaga atau sebuah organisasi publik yang akuntabel, mekanisme akuntabilitas harus mengandung empat (4) dimensi, yaitu (LAN, 2015):

a) Akuntabilitas kejujuran dan hukum (accountability for probity and legality), berkaitan dengan kepatuhan terhadap hukum dan peraturan yang diterapkan.

b) Akuntabilitas proses (processaccountability), berakaitan dengan: apakah prosedur yang digunakan dalam melaksanakan tugas sudah cukup baik dalam hal kecukupan sistem informasi akuntansi, sistem informasi manajemen dan prosedur administrasi. Akuntabilitas ini diterjemahkan dalam bentuk pelayanan yang cepat, responsif dan murah. Pengawasan aspek akuntabilitas proses bertujuan untuk menghindari praktek korupsi,kolusi dan nepotisme.

c) Akuntabilitas program (programaccountability), berkaitan dengan pemberian pertimbangan apakah tujuan yang ditetapkan dapat tercapai, dan apakah ada alternatif program lain yang memberikan hasil maksimal dengan biaya yang minimal.

d) Akuntabilitas kebijakan (policyaccountability), berkaitan dengan pertanggung jawaban organisasi atas kebijakan yang diambil terhadap lembaga legislatif dan masyarakat luas.

Selain unsur akuntabilitas, BMT juga sangat penting untuk menerapkan unsur transparansi sebagai upaya meningkatkan kepercayaan anggota dan masyarakat. Transparansi berarti terbukanya akses bagi semua pihak yang berkepentingan terhadap setiap informasi, seperti berbagai peraturan dan perundang-undangan, serta kebijakan organisasi dengan biaya yang 
minimal. Informasi sosial, ekonomi, dan politik yang andal dan berkala harus tersedia dan dapat diakses oleh publik.

Mardiasmo

(2011)

mendefinisikan transparansi (pada

aspek sektor publik) sebagai

keterbukaan pemerintah dalam

memberikan informasi yang terkait dengan aktivitas pengelolaan seumberdaya publik kepada pihak pihak yang membutuhkan informasi. Organisasi berkewajiban memberikan informasi keuangan dan informasi lainya yang akan digunakan untuk pengambilan keputusan oleh pihakpihak yang berkepentingan.

Solihat dan Sugiharto (2009;3) mendefinisikan trnasparansi sebagai minat dan upaya untuk saling kontrol melalui pemberian informasi tentang setiap kejadian penting dengan akurat dan tepat waktu dalam aspek kebijakan anggaran, dokumen anggaran, laporan pertanggungjawban, terakomodasinya usulan bagi publik, dan terdapat sistem pemberian informasi bagi publik.

Penerapan prinsip transparansi sangat penting bagi tujuan organisasi. Adapun tujuan dari transparansi adalah sebagai berikut (LAN, 2015):

a) Mendorong komunikasi yang lebih besar dan kerjasama antar kelompok internal dan eksternal,

b) Memberikanperlindungan terhadap pengaruh yang tidak seharusnya dan korupsi dalam pengambilan keputusan,

c) Meningkatkan akuntabilitas dalam keputusan-keputusan, dan

d) Meningkatkankepercayaan dan keyakinan kepada pimpinan dan secara keseluruhan.

\section{BMT}

BMT diartikan sebagai lembaga usaha ekonomi rakyat kecil, yang beranggotakan orang seorang atau badan hukum berdasarkan prinsip syariah dan prinsip koperasi (Rosyidin, 2004;10). Amerieska (2012;2) mendefinisikan BMT sebagai lembaga keuangan mikro yang dapat melayani kebutuhan nasabah usaha mikro kecil berdasarkan sistem syariah atau bagi hasil, dimana dalam kegiatannya BMT dibagi kedalam dua sisi kegiatan, yaitu Baitut Tamwil yang menempatkan pengembangan kegiatan-kegiatan investasi dan produktif, sedangkan Baitul Maal mengutamakan pada kegiatan-kegiatan kesejahteraan bersifat nirlaba yang diharapkan mampu mengakumulasi dana zakat, infaq dan shadaqah yang pada gilirannya berfungsi untuk mendukung kemungkinan risiko yang mungkin terjadi dalam kegiatan ekonomi pengusaha mikro dan kecil.

\section{METODE PENELITIAN}

Penelitian ini adalah penelitian lapangan (field research) dengan pendekatan kualitatif. Pendekatan ini digunakan untuk memperoleh informasi yang lebih mendalam tentang bagaimana implementasi prinsip-prinsip akuntabilitas dan transparansi dilaksanakan oleh BMT di Kota Surakarta, dengan studi secara khusus pada BMT Al-Madinah, dengan tujuan untuk menggali informasi bagaimana prinsip-prinsip akuntabilitas dan transparansi diimplementasikan pada pengelolaan BMT. Penelitian ini akan dilaksanakan pada tahun 2018.

Data yang digunakan dalam penelitian ini adalah data primer, yaitu data yang didapatkan langsung oleh peneliti dari objek penelitian tanpa melalui orang atau lembaga lain (Hadi, 2006: 39). Data primer pada penelitian ini diperoleh melalui dokumentasi, observasi dan wawancara dengan pihak pengelola BMT Al-Madinah.

Pengumpulan data dalam penelitian ini dilakukan dengan 
menggunakan teknik wawancara, yang didukung pula dengan observasi dan dokumentasi. Wawancara dalam penelitian ini dilakukan oleh peneliti terhadap informan yang dinilai mengetahui tentang fokus penelitian (akuntablitas dan transparansi) yaitu manajer umum, manajer pembiayaan atau pendanaan dan bagian keuangan (akuntansi) yang ada di BMT yang diteliti. Teknik dokumentasi digunakan oleh peneliti untuk mendapatkan informasi-informasi penting yang berhubungan dengan masalah penelitian. Informasi melalui teknik dokumentasi ini berupa buku-buku, jurnal,bukti dokumen yang dimiliki oleh setiap BMT yang diteliti dan juga website.

Data yang diperoleh dalam penelitian ini selanjutnya dianalisis dengan metode analisis deskriptif, yaitu metode yang bertujuan untuk memberikan gambaran mengenai objek penelitian berdasarkan data yang berhasil dikumpulkan, dari mulai tahapan pengumpulan data, reduksi data, penyajian data, hingga tahapan akhir yaitu penarikan kesimpulan (Sugiyono, 2017:249).

\section{HASIL PENELITIAN DAN PEMBAHASAN}

\section{Deskripsi Data Hasil Penelitian}

Berdasarkan hasil dokumentasi melalui profile dan data-data serta informasi yang dipublikasikan oleh BMT, dan diperkuat dengan beberapa data hasil wawancara yang dilalakukan dengan informan yaitu pimpinan BMT Al-Madinah yang dilaksanakan pada tanggal 20 Juli 2018 diperoleh data diantaranya sebagai berikut:

a) Berkaitan dengan badan hukum BMT
"BMT kita ini Badan hukumnya adalah KSU, karena badan hukumnya KSU, sesuai peraturan yang ada dan semangat para pendiri BMT, usahanya tidak boleh hanya satu jenis bidang usaha, melihat perkembangan yang ada, untuk unit USPPS (Unit Simpan Pinjam dan Pembiayaan Syariah) nya sementara kita tidak terlalu optimalkan mulai tahun 2017, karena memang kita tahu sekarang ini cukup sulit bagi lembaga keuangan nonbank untuk bersaing dengan perbankan. Sebagai koperasi, kita juga setiap tahun telah membuat laporan kepada kementerian koperasi”.

b) Berkaitan dengan struktur dan peran DPS?

“...Iya kita punya DPS mas, DPS kita jumlahnya 3 orang, yaitu bapak Drs. Farid Ma'ruf, Bapak Drs. Ust. H. Jawari dan Bapak H.M. Amir, SH”.

“... sebenarnya kalau mau jujur, secara umum lembaga keuangan syariah itu DPS nya juga optimalisasi mereka untuk bekrja di lembaga keuangan syariah masih kurang, hanya secara formalitas saja, punya sertifikat, sertifikasi, apakah betul dia mengawasi? apa betul dia terlibat dalam setiap produk? ya paling hanya dimintakan saja fatwa, pendapat, produk sudah kita buat, SOP sudah kita buat, DPS hanya mengesahkan saja”.

c) Berkaitan dengan pelanggaran dan perlakuannya

“...di kita pernah terjadi kasus pelanggaran oleh karyawan, dan 
ini belum lama. Untuk yang ketahuan melakukan pelanggaran, itu kita tidak ada toleransi, karena ini dampaknya sangat merugikan, dan ini juga menjadi salah satu pertimbangan kita mengurangi porsi USPPS karena disitu rawan sekali terjadinya penyalahgunaan, karena pola kerjanya kan kalau BMT jemput, dan ini sangat rawan, makanya USPPSnya kita kurangi porsinya".

“... kita pernah blajar dengan kospin jasa jadi semua transaksi itu terekam, ya pakai handphone itu bisa, tabungan pembiayaan itu saldo nya itu ada di $h p$ masing-masing. Hanya pesoalannya itu disamping dengan biaya yang cukup mahal, ditambah lagi masih bisa saja terjadi proud...sehingga itu juga masih kita kaji”.

d) Berkaitan dengan apresiasi atas kinerja karyawan

"Ada, misalnya karyawan yang punya sertifikat keahlian investasi, itu akan menjadi poin dalam penilaian e-person, yang pada saatny dia akan dipromosikan menjadi manajer".

e) Berkaitan dengan pencatatan keuangan

"Di kita pencatatan sudah menggunakan sistem, untuk keuangannya kita setiap unit usaha membuat laporan keuangan, lalu nanti laporan dari setiap unit akan dijadikan satu oleh bagian keuangan umum. Dan semuanya sudah menggunakan sistem. f) Berkaitan dengan masukan dan saran dari anggota

"Masing-masing kelompok sudah punya draft masukannya apa-apa,apa-apa begitu, biasanya kita punya petugas marketing yang mengkoordinir, dan yang paling efektif menurut kita selama ini ya menggunakan media handphone. Oleh karena itu, wajib anggota itu memiliki $H P$, yang nanti melalui media HP ini dibuat kelompokkelompok yang dikoordinir oleh marketing BMT, dimana pengelompokannya berdasarkan wilayah".

g) Berkaitan dengan pencapaian target

"Pencapaian target $y a,$, berkisar pada angka 75\%, belum bisa sampai 100\%, tetapi pernah di tahun 2015 kinerja keuangan mencapai angka diatas 100\%, baik dari pertumbuhan aset maupun kinerja keuangan lainnya, yang salah satunya disebabkan karena saat itu masih belum begitu kompleks masalah yang dihadapi oleh BMT, termsuk masalah persaingan dengan lembaga perbankan melalui berbagai kredit mikronya".

h) Berkaitan dengan perkembangan unit usaha riil BMT

"Kita ada beberapa unit usaha riil, diantaranya ada warung makan yaitu warung sate lawu yang ada di daerah jajar sendiri dan ada lagi yang berlokasi di tawangmangu, juga sekarang sedang kita kembangkan lagi resto dengan konsep wisata religi, dimana ini masih sedang dalam proses pengembangan 
yang kedepan diharapkan dapat menjadi solusi bagi para calon wisatawan khususnya kalau wisatawan dalam negeri.....".

i) Berkaitan dengan transparansi melalui keterlibatan anggota "kalau sudah diatas minimal 500 anggota itu boleh ada perwakilan, yang sudah-sudah itu 50an orang, tetapi di angaran dasar kan sudah kita atur, setiap satu orang bisa mewakili berapa orang. Anggota kita secara keseluruhan ada sekitar 700 orang.

“... Kita tidak lagi memberikan undangan lewat undangan yang tertulis, karena biasanya kita sekarang ini kankalau dapat surat dari mana saja jarang sekali langsung kita baca, tapi kalau pesan lewat HP, pasti langsung dibaca, tetapi tetap surat tettulis juga kita buat sebagai arsip dan tentunya bahan yang akan dishare di HP.

j) Berkaitan dengan penyampaian informasi dalam RAT

"Yang disampaikn ya tentang pertanggung jawaban kinerja selama setahun, laporannya itu dari RAPB tahun sebelumnya, punya program-progamnya apa, program bagian keuangan apa, program bagian manajemen apa, pengembangan usaha apa, dan setursnya, pencapaiannya bagaimana, lalu apakah diterima atau tidak? Kalau sudah, lalu penyampaian program kerja tahun berikutnya.

k) Berkaitan dengan penggunaan media untuk transparansi
"Iya, betul, karena menurut kita, sekarang ini yang paling efektif ya lewat HP itu".

\section{Analisis dan Pembahasan}

a. Penerapan Prinsip Akuntabilitas pada Pengelolaan BMT Al-Madinah Surakarta.

Akuntabilitas merupakan kewajiban seseorang, unit organisasi, atau institusi untuk mempertanggungjawabkan apa yang menjadi amanahnya dalam mengelola dan mengendalikan sumberdaya dalam rangka pencapaian visi, misi dan tujuan yang telah ditetapkan melalui media pertanggung jawaban secara berkala (Sedarmayanti, 2003; Rakhmat, 2009; LAN, 2015). Akuntabilitas pada penelitian ini difokuskan pada 3 dimensi, yaitu akuntabilitas hukum, akuntabilitas proses, akuntabilitas program.

1) Akuntabilitas Hukum

Akuntabilitas hukum merupakan perwujudan pertanggungjawaban.

seseorang, unit organisasi atau institusi terhadap perundangundangan atau peraturan yang telah ditetapkan (Wasistiono, 2003; LAN, 2015). Sebagai lembaga keuangan, BMT berkaitan dengan dua peraturan yang harus dipenuhi, Pertama kaitannya BMT sebagai sebuah koperasi yang harus mematuhi ketentuan perkoperasian, Kedua, kaitannya dengan BMT sebagai lembaga keuangan mikro syariah yang harus memenuhi ketentuan syari'ah dalam kegiatan operasionalnya. 
a) BMT Al-Madinah sebagai koperasi. Berdasarkan data hasil wawancara dan didukung oleh dokumen terkait yang tertera dalam profile BMT Al-Madinah, BMT Al-Madinah telah sesuai dengan ketentuan hukum perkoperasian dengan aspek legalitas berupa Surat izin berdasarkan SK Badan Hukum No. 14283/BH/XIV/X/2011

tanggal 18 Oktober 2011. Selain itu, BMT AlMadinah juga telah melakukan pelaporan secara periodik atau laporan tahunan yang disampaikan kepada kementerian koperasi.

b) BMT Al-Madinah sebagai lembaga keuangan mikro syariah berdasarkan hasil wawancara yang dilakukan dan bukti dokumentasi yang terkait, juga secara formal sudah memenuhi ketentuan syariah dengan memiliki struktur dewan pengawas syariah (DPS) yang berjumlah 3 orang DPS. Adapun fungsi DPS yang ada di BMT Al-Madinah juga sebagaimana pada lembaga keuangan syariah lainnya khususnya BMT sudah dilaksanakan, yaitu dalalm bentuk memberikan pendapat dan pandangan terhadap produk, program dan operasional yang telah disusun oleh pengurus dan pengelola BMT untuk selanjutnya dapat dilaksanakan.
Meskipun secara faktual peran DPS belum dilaksanakan secara ideal di BMT Al-Madinah, akan tetapi secara substansi, pengurus dan pengelola BMT selalu berusaha untuk meningkatkan kepatuhan terhadap aspek syariah. Draft produk, operasional dan program yang diajukan kepada DPS sudah dibuat sedemikian rupa dengan penuh kehati-hatian mengacu kepada peraturan hukum dan ketentuan fatwa yang telah ada, berdasarkan pengetahuan dan kemampuan para pengurus dan pengelola BMT AlMadinah.

Masih berhubungan pula dengan akuntabilitas secara hukum, pihak BMT juga berdasarkan data hasil observasi dan wawancara yang sudah dipaparkan diatas, BMT Al-Madinah selalu berupaya untuk mematuhi peraturan berkaitan dengan produk baik penghimpunan maupun penyaluran dana.

Pada produk penghimpunan dana misalnya, pihak BMT selalu berusaha menjelaskan kepada nasabah yang akan melakukan investasi dengan akad mudharabah, diberikan penjelasan tentang akad yang digunakan berserta dengan berbagai konsekuensi, kemungkinan dan proyeksi hasilnya.

2) Akuntabilitas Proses

Akuntabilitas proses berakaitan dengan: apakah 
prosedur yang digunakan dalam melaksanakan tugas sudah cukup baik dalam hal kecukupan sistem informasi akuntansi, sistem informasi manajemen dan prosedur administrasi (LAN,2015). Berdasarkan deskripsi data yang diperoleh dari hasil wawancara dan didukung pula dengan hasil pengamatan dan dokumen yang terkait, BMT Al-Madinah telaah melaksanakan prinsip akuntabilitas proses dalam bentuk sebagai berikut:

a) Berkaitan dengan prosedur administratif, BMT AlMadinah telah membuat jobdescription bagi seluruh bagian/unit yang ada, baik unit usaha simpan pinjam dan pembiayaan syariah maupun unit sektor riil,sehigga diharapkan kinerja setiap bagian menjadi optimal, karena sudah ada kejelasan tugas masing-masing.

b) Berkaitan dengan sistem informasi, BMT AlMadinah juga dalam pengelolaan keuangan khussnya aspek akuntansinya sudah menggunakan sistem informasi akuntansi, yaitu dengan menggunakan UC.

3) Akuntabilitas Program

$$
\begin{aligned}
& \text { berkaitan dengan } \\
& \text { pertimbangan-pertimbangan } \\
& \text { dalam penyusunan program } \\
& \text { untuk dapat merealisasikan } \\
& \text { tujuan yang telah ditetapkan } \\
& \text { (LAN, 2015). Berdasarkan data } \\
& \text { yang diperoleh dari hasil }
\end{aligned}
$$

observasi dan wawancara dengan pimpinan BMT AlMadinah, prinsip akuntabilitas program telah dilaksanakan oleh BMT Al-Madinah dengan bentuk sebagai berikut:

a) Pengajuan badan hukum BMT sebagai Koperasi Serba Usaha Syariah (KSUS). Sejak awal pendiriannya, pengelola BMT Al-Madinah berorientasi untuk mengembangkan ekonomi masyarakat dengan tidak hanya berfokus melalui aspek pelayanan jasa keuangan, tetapi juga dengan pemberdayaan melalui bentuk-bentuk usaha dan kegiatan yang lain, sehingga jenis koperasi yang dari awal berdiri dibentuk sebagai koperasi serba usaha.

b) Pencapaian tujuan atau target melalui program yang dilaksanakan. Pada aspek ini, BMT Al-Madinah melaksanakan prinsip akuntabilitas dengan mengupayakan setiap program yang berkaitan dengan kelima unit usaha untuk dapat mencapai target yang telah ditetapkan. Akuntabilitas ini terbukti dengan adanya pencapaian target melalui program yang dilakukan yang capaiannya selalu diatas $75 \%$, bahkan di tahun 2015 pertumbuhan aset BMT pernah mencapai hasil yang melebihi target yang direncanakan.

c) Pelibatan partisipasi dan peran anggota untuk memaksimalkan pencapaian 
target. Pada aspek ini, prinsip akuntabilitas program dilaksanakan oleh BMT Al-Madinah melalui pelibatan peran dan kontribusi dari para anggota. Bentuk pelibatan tersebut dilakukan melalui mekanisme RAT dan pemanfaatan media whatsapp. Setiap tahun sebelum dilaksanakannya kegiatan RAT, pihak pengurus menyampaikan rencana RAT sekaligus penyampaian pencapaian kinerja tahun sebelumnya dan rencana tahun yang akan datang, sehingga setiap anggota dapat mempersiapkan berbagai saran dan masukan untuk rencana dan target di tahun yang akan datang.

\section{b. Penerapan Prinsip Transparansi pada Pengelolaan BMT Al-Madinah Surakarta}

Transparansi merupakan keterbukaan akses bagi semua pihak yang berkepentingan terhadap setiap informasi. Mardiasmo mendefinisikan trnsparansi sebagai keterbukaan dalam memberikan informasi berkaitan dengan pengelolaan sumber daya kepada pihak-pihak yang membutuhkan informasi.

Pada BMT Al-Madinah Surakarta, prinsip tranasparansi diimplementasikan melalui kegiatan rapat anggota tahunan (RAT) yang dalam kegiatan tersebut disampaikan program kerja tahun sebelumnya baik dari sisi keuangan, manajemen dan pengembangan usaha, dan pencapaiannya selanjutnya dibahas rencana kerja tahun berikutnya. Sebagai bentuk transparansi sekaligus akuntabilitas, karena jumlah anggota sudah mencapai 700 orang, maka peserta yang mengikuti RAT adalah perwakilan dari seluruh anggota, yaitu sebanyak 50 orang, dengan mekanisme pemilihan yang dilakukan dengan pendelegasian dari masing-masing grup wilayah. Bentuk dari prinsip transparansi lainnya yang diimplementasikan di BMT AlMadinah adalah melalui optimalisasi pemanfaatan media handphone. BMT mengharuskan setiap anggota untuk memiliki handphone sehingga memudahkan untuk penyampaian informasi. Melalui handphone (khususnya whatsapp), BMT dapat menyampaikan berbagai informasi kepada anggota, sebaliknya juga anggota juga dapat secara langsung menyampaikan informasi atau kepentingan lain yang berhubungan dengan BMT.

Melalui media WA juga, BMT menyampaikan informasi berkaitan dengan kegiatan RAT dengan menyampaikan draft rencana kerja periode yang akan datang, dan laporan keuangan sebagai pencapaian kinerja keuangan tahun sebelumnya, sehingga anggota sudah mempersipkan berbagai masukan dan saran untuk rencana kerja berikutnya yang akan dibahas dalam agenda RAT. Selain itu, melalui WA pihak BMT juga dapat secara lebih efektif dan efisien untuk menyampaikan 
berbagai kegiatan-kegiatan atau program yang dilaksanakan termasuk pula menyampaikan undangan-undangan kegiatan bagi anggota.

Selain melalui media RAT dan pemanfaatan media handphone, BMT Al-madinah juga menerapkan prinsip transparansi pengelolaan BMT melalui pemanfaatan media internet yaitu dengan membuat website BMT Al-Madinah, hanya saja karena kendala SDM yang harus lebih banyak fokus untuk mengoptimalkan kinerja pada pengelolaan kegiatan usaha BMT, maka sejak tahun 2015 hingga skarang, website yang telah dibuat belum dapat dioptimalkan lagi sebagai media penyampaian informasi baik kepada anggota maupun kepada publik.

Beberapa sarana publikasi sebagai bentuk transparansi telah dilaksanakan oleh BMT Al-Madinah Surakarta, namun disamping masih adanya kendala teknis berkaitan dengan pemanfaatan yang lebih optimal lagi berkaitan dengan publikasi melalui media internet, berdasarkan hasil pengamatan peneliti di Kantor BMT, BMT AlMadinah juga masih kurang mengoptimalkan fungsi kantor untuk mempublikasikan programprogram yang telah dilaksanakan, pencapaian target sekaligus perkembangan kondisi keuangan atau kinerja BMT kepada anggota dan juga kepada masyarakat. Namun demikian, berdasarkan hasil wawancara dengan ketua pengurus BMT Al-Madinah, saat ini BMT Al-Madinah masih berfokus memanfaatan whatsapp (WA) untuk publikasi kepada anggota, karena dirasa lebih efektif dan efisien dibandingkan dengan sarana lainnya.

\section{SIMPULAN DAN SARAN}

Berdasarkan deskripsi data dan analisis pada bagian sebelumnya, pada penelitian ini dapat disimpulkan bahwa BMT Al-Madinah telah menerapkan prinsip akuntabilitas dan transparansi melalui:

1. kepatuhan terhadap pemenuhan aspek legal kelembagaan dan pemenuhan syarat keberadaan DPS dan pelaksanaan peran DPS sebagai bentuk akuntablitas hukum.

2. adanya jobdescription seluruh unit yang ada sekaligus adanya reward and punishment bagi seluruh karyawan dan penerapan sistem informasi dalam pelaksanaan fungsi keuangan/akuntansi sebagai bentuk dari akuntablitas proses.

3. pelaksanaan program yang selalu diupayakan untuk mencapai target dan pelibatan peran anggota BMT dalam penentuan rencana program dan target yang akan dicapai sebagai bentuk dari akuntabilitas program.

4. mekanisme RAT untuk menyampaikan kinerja yang telah dicapai dan rencana kerja periode berikutnya, penyampaian berbagai informasi melalui whatsapp juga internet dengan membuat website BMT Al-Madinah meskipun pengelolaanya belum dioptimalkan kembali.

Meskipun secara umum prinsipprinsip akuntablitas dan transparansi telah dilaksanakan oleh BMT AlMadinah pada pengelolaan BMT, namun masih ada beberapa aspek operasional yang belum dilaksanakan sebagai bagian dari prinsip akuntablitas dan transparansi, diantaranya yaitu: 
1. Pada pelaksanaan tugas DPS, pelaksanaannya di BMT ALMadinah belum dilakukan secara lebih optimal, yaitu belum adanya koordinasi rutin yang dilaksanakan antara DPS dengan pengelola BMT.

2. Pada kegiatan teknis atau proses kerja, BMT Al-Madinah sudah memiliki Jobdeskripsi untuk masing-masing unit, tetapi belum dikembangkan pada adanya SOP yang dapat semakin meningkatkan pelaksanaan tugas kerja oleh masing-masing unit dan karyawan BMT.

3. BMT Al-Madinah belum mengoptimalkan fungsi media off line, yaitu ruang kantor yang setiap hari diakses oleh anggota dan masyarakat, untuk mempublikasikan programprogram penting dan perkembangan keuangan BMT.

\section{DAFTAR PUSTAKA}

Amerieska, Siti. Irianto, Gugus. Affandi, Didied P. (2012). Akuntabilitas Baitul Maal wa Tamwil ditinjau dari Shari'a Enterprise Theory. Jurnal Ekonomi dan Keuangan Islam Vol. 2 No.1.

Basrowi dan Suwandi. 2004. Memahami Penelitian Kualitatif. Rineka Cipta. Jakarta.

Hadi, Syamsul. 2006. Metodologi Penelitian Kuantitatif untuk Akuntansi dan Keuangan. Ekonisia. Yogyakarta.

Hariswati, Nurul. 2015. Analisa akuntabilitas dan transparansi Tentang implementas ikebijakan Pengelolaandana BOS. Ekonomika-BisnisVol. 6 No.1.

Jayanti, Ika Puspita. Sjamsuddin, Sjamsiar . Wachid, Abdul. Reformasi pengelolaan keuangan daerah Dalam rangka mewujudkan transparansi dan akuntabilitas (Studi Pada Pemerintah Kota Malang).Jurnal Administrasi Publik (JAP), Vol. 2, No.2.

Leno, Darius. 2013. Analisis Penerapan SAK No.101 pada KSPS BMT Muhammadiyah Rasau. Jurnal KIAFE UNTAN, Vol.2 No.3.

Nahruddin, Zulfan. 2014. Akuntabilitas dan transparansi pengelolaan dana alokasi desa Di desa pao-pao kecamatan tanete rilau Kabupaten barru. OTORITAS Jurnal Ilmu Pengetahuan, Vol. IV, No.2.

Pujiyono, Arif. 2013. Semnas Fekon: Optimieme Ekonomi Indonesia 2013: antara Peluang dan Tantangan.

Ridwan, Muhamad. 2004. Manajemen Baitul Maal wa Tamwil. UII Press. Yogyakarta.

Rizki, Awalil. 2004. BMT "Fakta dan Prospek BMT”. UCY Press. Yogyakarta

Rosidin, Ahmad Dahlan. 2004. Lembaga Mikro dan Pembiayaan Mudharabah. Global Pustaka Utama. Yogyakarta.

Sedarmayanti. 2003. Good Governance

(Kepemerintahan Yang Baik) Dalam Rangka Otonomi Daerah,. Bandung: Mandar Maju. 
Solihat, Eli. Sugiharto, Toto. 2009. Pengaruh Akuntabilitas dan Transparansi Pengelolaan Pendidikan terhadap Partisipasi Orang Tua Murid di SMA Negeri 107 Jakarta. Jurnal Ekonomi Bisnis, Vol. 14 No. 2.

Sudarsono, Heri. 2007. Bank dan Lembaga Keuangan Syariah. Ekonisia. Yogyakarta.

Sugiyono. 2010. Metodologi Penelitian Pendidikan Penelitian Pendekatan Kualitatif, Kuantitatif dan $R \& D$. Alfabeta. Bandung. http://yskk.org/transparansi-danakuntabilitas-kuncikeberlangsungan-koperasi, diakses pada 20 Juli 2017. http://businesslaw.binus.ac.id/2017/03/31/se kilas-tentang-lembagakeuangan-mikro-syariah-diindonesia/, diakses pada 20 Juli 2017.

http://www2.jawapos.com/baca/arti kel/20729/Geledah-KantorBMT Penggelapan-MiliaranDana-Nasabah-Polisi-SitaKomputer, diakses pada 20 Juli 2017.

http://www.kebumenekspres.com/2 017/02/nasabah-bmt-diwonogiri-resahtabungan.html, diakses pada 20 Juli 2017.

Wasistiono, Sadu. 2003. Kapita Selekta Penyelenggaraan Pemerintah Daerah. Bandung: Fokus Media. 